\author{
Килинчук О. $€$. \\ кандидат економічних наук, старший викладач \\ кафедра туристичного бізнесу та рекреації \\ Одеська національна академія харчових технологій \\ вул. Канатна, 112, г. Одеса, Україна, 65039 \\ E-mail:Kilinchyk@gmail.com
}

\title{
ВЛИВ ГУДВІЛУ НА ПІДВИЩЕННЯ КОНКУРЕНТОСПРОМОЖНОСТІ У ТУРИЗМІ
}

\begin{abstract}
У статті розглянуто основні показники, які формують позитивний гудвіл туристичного підприємства та їх вплив на конкурентоспроможність. Обґрунтовано потенціал гудвілу, як сукупність характерних поведінкових рис туристичної компанії, напрацьованих за час ії̈ перебування на туристичному ринку. Запропоновано складові репутаційного потенціалу туристичного підприємства, як сукупність фракторів невловимого характеру, що включають аспекти відношень між туристичним підприємством та клієнтами.
\end{abstract}

Ключові слова: конкурентоспроможність, гудвіл, туризм, туристичний бізнес, ефрективність, конкуренція.

This work is licensed under a Creative Commons Attribution 4.0 International License http://creativecommons.org/licenses/by/4.0/

Постановка проблеми та її зв'язок 3 важливими науковими та практичними завданнями. На даний час важливою проблемою щодо прийняття рішення про вибір ефективної політики фірми в сфері туристичного бізнесу є проблема управління гудвілом туристичних фірм, оскільки гудвіл, є частиною необоротних активів. Виходячи з цього, розробка рекомендацій допоможе менеджменту туристичних фірм істотно підвищити ступінь конкурентоспроможності та ефективності операційної діяльності. Актуальність даної проблеми чітко видна на ринку туристичних послуг в умовах сьогоднішньої фінансової нестабільності.

Аналіз останніх публікацій по проблемі. Велике значення для вивчення і оцінки формування гудвілу підприємства мають роботи вітчизняних i зарубіжних авторів, зокрема Г. Уманців у своїх роботах розглядала проблеми оцінки та особливості обліку гудвілу, П. Сук. розглядав гудвіл у розрізі нематеріальних активів, Самсонов В., Марченко С. займались питаннями оцінки гудвілу. Спробу розкрити взаємозв'язок між поняттями імідж і репутація у своїх дослідженнях робить Р. Даулінг [16], який обгрунтовує, що «сприятлива репутація компанії допомагає підтримувати іiі ділову активність, а за поліпшення репутації необхідно платити». Дослідженню визначення як сутності, так й економічної ролі ділової репутації присвячені праці Р. Харлоу, С. Фомбрана, Т. Харpica, Г. Девайса [3-6].

Формулювання мети та завдань статті. Метою статті є дослідження впливу гудвілу на конкурентоспроможність туристичного підприємства. Об'єктом дослідження є конкурентоспроможність туристичного підприємства та вплив гудвілу на неї.
Предметом дослідження є теоретичні, методичні та практичні засади управлінських відносин, пов'язаних iз формуванням ефективного гудвілу підприємства.

Виклад основних результатів та їх обгрунтування. Ефективність туристського бізнесу багато в чому визначається зовнішніми факторами функціонування туристських організацій. Основоположним зовнішнім фактором є конкурентна середа суб'єктів туризму, яка в сучасних економічних умовах відрізняється високим ступенем невизначеності, оскільки передбачає безліч суб'єктів господарювання, цілі та мотиви яких передбачити досить важко.

Розуміння конкурентного середовища туризму вимагає вивчення основ конкуренції як економічної категорії. Конкуренція в туризмі - це боротьба між туристськими організаціями за найбільш вигідні умови виробництва і збуту з метою досягнення кращих результатів своєї підприємницької діяльності.

Основний зміст конкуренції в туристському секторі економіки - боротьба за споживача - туриста, повне задоволення його потреб. Це боротьба за частку ринку, успіх якої залежить від дешевизни і якості туристичних продуктів і послуг. Конкуренція перетворює споживача в індикатор туристського бізнесу [1].

Для досягнення максимальної ефективності бізнесу туристська організація повинна контролювати макроекономічні чинники конкурентного середовища (демографічні, економічні, технологічні, політикоправові та соціально-культурні) і мікрофактори конкурентного середовища (споживачі, конкуренти, канали розподілу, постачальники). Ці фактори впливають на здатність туристської організації отримувати прибуток на ринку, тому їх необхідно відстежувати, 
щоб своєчасно виявити зміни цих факторів і головні тенденції в їхньому розвитку. У кожній з цих тенденцій організація повинна виявити приховані сприятливі можливості і загрозливі фактори для свого бізнесу [2].

В практиці українського туристичного бізнесу недооцінена іміджева складова, тому немає стійких зв'язків між репутацією та ціною бізнесу. Гудвіл сприяє збільшенню привабливості підприємства для інвесторів, підвищує його капіталізацію, підсилює позиції при виході на нові ринки й підтримку широких верств населення. Вплив росту гудвілу та його зміцненню на підвищення економічних показників туристичного підприємства проявляється через поведінку та зацікавленність клієнтів, які купують послуги підприємства; інвесторів, які вкладають капітал в акції підприємства; партнерів, що довіряють підприємству; співробітників; місцеве співтовариство. Оцінка економічної сутності гудвілу все більше цікавить туристичні підприємства у зв'язку з нестабільністю ринків [7].

Сутність гудвілу полягає в тому, що він являє собою частину репутації, яка може бути позитивною або негативною. Відповідно до законодавства гудвіл належить підприємству 3 моменту його утворення та державної реєстрації, і становить невід’ємну частину правоздатності юридичної особи. У визначенні гудвілу підприємства доцільно поєднати два критерії: поперше, це громадська думка, що склалася у сфері ділового обороту; по-друге це наднормативний прибуток і фактор сталого функціонування. Отже, гудвіл це суспільно сформована думка щодо переваг та недоліків туристичного підприємства, що визначає відношення до нього і впливає на прибуток та стійкість функціонування [8].

Під «потенціалом гудвілу» пропонується розуміти сукупність характерних поведінкових рис туристичної компанії, напрацьованих за час іiі перебування на туристичному ринку. Потенціал гудвілу або репутаційний потенціал $є$ на кожному підприємстві, але він може бути невідомим для туристичного ринку, тому на підприємстві недостатній рівень репутаційного менеджменту туристичного підприємства. Отже, під репутаційним потенціалом необхідно розуміти сукупність факторів невловимого характеру, що включають аспекти відношень між туристичним підприємством та клієнтами [9].

Розглянемо складові репутаційного потенціалу туристичного підприємства.

1. Організаційна культура. Інвестування в організаційну культуру туристичного підприємства стають довгостроковим фактором конкурентоспроможності туристичного підприємства. Підприємства 3 яскраво вираженою організаційною культурою ефективніше використовують як матеріальні, так і людські ресурси. Як відомо, в економіці багатьох країн, i України зокрема, протягом останніх десятиліть спостережено значне зростання значення сфери послуг, у межах якої туризм відіграє одну з головних ролей. Найбільшим успіхом користуються саме ті туристичні підприємства, у яких працівники ототожнюють себе з компанією, розуміють об'єктивну необхідність досягнення єдності особистих інтересів та інтересів фірми, тобто там, де формується і підтримується висока організаційна культура. Запропонована модель формування та розвитку організаційної культури туристичного підприємства дозволяє цілеспрямовано та ефективно використовувати ресурси туристичного підприємства [10].

2. Організаційна структура. До сучасних організаційних структур управління висувають низку об'єктивних і універсальних вимог, зумовлених загальноекономічними і організаційними факторами та умовами, дотримання яких дає змогу організації ефективно функціонувати:

- відповідність цілям і завданням організації, відповідно, підпорядкування виробничообслуговуючій діяльності та їі вимогам;

- оптимальний поділ праці між органами управління та окремими працівниками, що забезпечує спеціалізацію, творчий характер роботи і раціональне навантаження;

- взаємозв'язок кожного працівника, на якого покладено певні повноваження і відповідальність, й органу управління шляхом реалізації вертикальних i горизонтальних зв'язків між ними;

- відповідність між функціями й обов'язками, з одного боку, та повноваженнями і відповідальністю - 3 іншого (порушення цієї вимоги приводить до дисфункції системи управління в цілому);

- адекватність соціально-культурному середовищу організації;

- надійність, тобто структура апарату управління повинна гарантувати достовірність передачі інформації, не допускати викривлення управлінських команд, забезпечувати безперебійний зв'язок у системі управління;

- адаптивність і гнучкість відповідно до змінних умов зовнішнього середовища (розширення зони туристичного обслуговування, урахування зміни у смаках і потребах споживачів тощо);

- економічність, тобто досягнення запланованого ефекту від функціонування структури за мінімальних витрат на управлінський апарат [11].

3. Соціальна відповідальність підприємства, iii актуальність та формування в туризмі обумовлена тим, що корпоративна соціальна відповідальність спроможна забезпечити: посилення іміджу та ділової репутації підприємства; підвищення інвестиційної привабливості; зміцнення згуртованості трудового колективу; соціальний внесок у стійкий розвиток регіону; зростання капіталізації суб'єкта діяльності.

Формування корпоративної соціальної відповідальності в туризмі $\epsilon$ вагомим чинником створення контрольованого мезосередовища, цілеспрямованого підвищення рівня конкурентоспроможності туристичних підприємств та забезпечення досягнення цілей стійкого розвитку туризму [12].

4. Ставлення з контрагентами.

5. Інноваційна діяльність підприємства. Зміна економічних пріоритетів, бізнес-середовища функці- 
онування, високу ступінь невизначеності та коливання попиту на ринку, важкопрогнозованості наслідків криз та інших негативних факторів впливу спонукають туристичні підприємства до винайдення шляхів подальшого розвитку, які лежать в площині інноваційних перетворень як підприємницької складової ринкових змін, так і розвитку нових форм і методів управління. Успішні інноватори туризму своїм досвідом доводять, що створення і впровадження нового не просто бажано, але і необхідно в конкурентній боротьбі, а в період економічної нестабільності, це повинно сприйматися як умова виживання [13].

6. Вартість підприємства на ринку.

7. Економічна діяльність.

8. Кадри підприємства. При цьому деякі питання кадрового забезпечення туристичної галузі потребують вирішення на рівні центральних органів виконавчої влади. Передусім це якість підготовки фахівців, рівень навчальних програм, планів, методичних розробок та їх адаптація до вимог сучасного міжнародного туристичного ринку. Підвищенню якості підготовки фахівців, безумовно, сприятиме введення $з$ 2002-2003 навчального року до Переліку напрямів та спеціальностей, за якими здійснюється підготовка фахівців у вищих навчальних закладах за відповідними освітньо-кваліфікаційними рівнями, затвердженого постановою Кабінету Міністрів України від 24 червня 1997 р. № 507, напряму 0504 «Туризм» (Наказ Міністерства освіти і науки України № 241 від 08.04.2002 p. і за погодженням з Кабінетом Міністрів України від 28 березня 2002 р. № 3694/33) [14].

9. Місцезнаходження.

10. Дизайн інтер'єру.

11. Якість продукції.

12. Маркетингова діяльність. На даному етапі розвитку ринкових відносин на туристичному ринку України будь-яке підприємство не може ефективно функціонувати без застосування маркетингового інструментарію та вмілого процесу управління ним. Адже він передбачає визначення свого положення на ринку, аналіз можливостей, вивчення ринкового середовища функціонування, аналіз рівня конкурентної боротьби, прогноз зміни кон'юнктури ринку, визначення стратегії розвитку тощо. Кінцевою метою результативного управління маркетинговою діяльністю має стати раціональна взаємодія зовнішнього та внутрішнього середовища функціонування туристичного підприємства, вміле використання його потенціалу як основи формування маркетингових можливостей.

13. Участь у діяльності інших організацій $[15]$.

Управління діловою репутацією доцільно зосередити на вищих рівнях організаційної структури організації, для того, щоб повною мірою отримати приховані в гудвіл стратегічні та фінансові вигоди. При цьому важливо дотримуватися збалансований інвестиційний підхід до створення змісту репутації, здійсненню сполучених 3 нею комунікацій як всередині, так і поза компанією, що, з часом, призведе до збільшення вартості гудвілу, як активу, i, як наслідок, зростанню ринкової капіталізації компанії.

Висновки і перспективи подальших досліджень. Таким чином, в цілях підвищення конкурентоспроможності туристичного підприємства необхідно стратегічне управління гудвілом як серйозною конкурентною перевагою. Керівництво туристичного підприємства повинно мати чітке уявлення про свою місію, чітку стратегію діяльності. Зростаюча конкуренція на ринку туристичних послуг примушує підприємців пов'язувати своє майбутнє 3 розвитком бізнесу своїх клієнтів, їх стратегічними цілями і завданнями. Туристичні підприємства зацікавлені в платоспроможних і сумлінних клієнтів. Управління ризиком втрати репутації повинно здійснюватися підприємствами з метою зниження можливих збитків, збереження та підтримання ділової репутації перед клієнтами та контрагентами, органами державної влади та місцевого самоврядування.

\section{Література}

1. Дмитриев М.Н. Экономика туристического рынка: [учебник] / Дмитриев М.Н., Забаева М.Н., Малыгина Е.Н. - М.: Юнити-Дана, 2010. - 312 с.

2. Темный Ю.В. Экономика туризма: [учебник] / Ю.В.Темный, Л.Р.Темная. - М.: Советский спорт, 2003. $-416 \mathrm{c}$.

3. Harlow R. F. Public relations definitions through the years / R. F. Harlow // Public Relations Review. 1977. - № 3 (I). - P. 49-63.

4. Fombrun C. What's in a name? Reputation building and corporate strategy / C. Fombrun, M. Shanley // Academy of Management Journal. - 1990. - № 33 (II). - P. 233-258.

5. Harris T. L. Value - Added Public Relations: The Secret Weapon of Integrated Marketing / T. L. Harris. Chicago, IL : McGraw Hill, 1988. - 304 p.

6. Davies G. Reputation management: theory versus practice / G. Davies, L. Miles // Corporate Reputation Review. - 1998. - № 2 (II). - P. 16-27.

7. Подольна В. Концептуальні основи гудвілу як нематеріального активу підприємства / В. Подольна // Сталий розвиток економіки. - 2011. - № 6. - С. 207-211.

8. Гоц Л. Методики визначення вартості гудвілу / Л. Гоц // Прометей. - 2012. - № 1 (37). - С. 140-143.

9. Зобкова Ж.О. Комплексный подход к оценке деловой репутации предприятия / Зобкова Ж.О., Пахомов А.В., Пахомова Е.А. // Математика. Компьютер. Образование: сб. тр. XV междунар. -конф. - Ижевск: Науч.- изд. центр «Регулярная и. хаотическая динамика». - 2008. - Т. 1. - С. 150-153.

10. Батурина О. Исследуем корпоративную культуру / О. Батурина // Кадровый менеджмент. - 2004. № 5(18). - C. 65-68.

11. Кіптенко В. К. Менеджмент туризму: [підручник] / В. К. Кіптенко. - К.: Знання, 2010. - 502 с. 
12. Шконда В.В. Корпоративна культура в управлінні людським потенціалом: [монографія] / В.В. Шконда, А.В. Кальянов. - Донецьк: Ноулідж (донецьке відділення), 2009. - 168 с.

13. Михайліченко Г.І. Інноваційний розвиток туристичних підприємств: напрями змін та фактори впливу [Електроний ресурс] / Г.І.Михайліченко // Економіка. Управління. Інновації. - 2012. - №1 (7). - Режим доступу : http://uk.lib-ebook.com/41 kulturologiya/1695159-1-udk-371134-33848-mihaylichenko-gi-ken-docent-doktorantkiivskiy-nacionalniy-torgovelno-ekonomichniy-universitet-innova.php

14. Про внесення змін до переліку напрямів та спеціальностей, за якими здійснюється підготовка фахівців у вищих навчальних закладах за відповідними освітньо-кваліфікаційними рівнями : Наказ Міністерства освіти і науки України № 241 від 08.04.2002 р. [Електронний ресурс] - Режим доступу: http://zakon.rada.gov.ua/cgi-bin/laws/main.cgi?nreg=z0854-04.

15. Чаплінський Ю.Б. Модель управління маркетинговою діяльністю туристичного підприємства [Електроний ресурс] / Ю.Б. Чаплінський // Вісник Чернівецького торговельно-економічного інституту. - 2011. Випуск I (41). - Режим доступу : http://www.chtei-knteu.cv.ua/herald/content/download/archive/2011/v1/NV-2011V1_42.pdf

16. Грем Даулінг. Репутація фірми. Створення, управління та оцінка ефективності / Грем Даулінг; пер. О.В. Кузнєцов. - М.: ІМІДЖ-Контакт, 2003. - 368 с.

Килинчук О. $€$.

кандидат экономических наук, старший преподаватель кафредра туристического бизнеса и рекреации

Одесская национальная академия пищевых технологий ул. Канатная, 112, г. Одесса, Украина, 65039

E-mail: Kilinchyk@gmail.com

\section{ВЛИЯНИЕ ГУДВИЛА НА ПОВЫШЕНИЕ КОНКУРЕНТОСПОСОБНОСТИ В ТУРИЗМЕ}

В статье рассмотрены основные показатели, которые формируют положительный гудвил туристического предприятия и их влияние на конкурентоспособность. Обоснован потенциал гудвила, как совокупность характерных поведенческих черт туристической компании, наработанных за время ее пребывания на туристическом рынке. Предложены составляющие репутационного потенциала туристического предприятия, как совокупность факторов неуловимого характера, включающие аспекты отношений между туристическим предприятием и клиентами.

На сегодняшний день важной проблемой для принятия решения о выборе эффективной политики фрирмы в сфере туристического бизнеса является проблема управления гудвилом туристических фирм, поскольку гудвил, является частью необоротных активов. Исходя из этого, разработка рекомендаций поможет менеджменту туристических фирм существенно повысить степень конкурентоспособности и эффективности операционной деятельности. Актуальность данной проблемы четко видна на рынке туристических услуг в условиях сегодняшней финансовой нестабильности. Эффективность туристического бизнеса во многом определяется внешними факторами функционирования туристических организаций.

Основополагающим внешним фактором является конкурентная среда субъектов туризма, которая в современных экономических условиях отличается высокой степенью неопределенности, поскольку предполагает множество субъектов, цели и мотивы которых предусмотреть достаточно трудHO.

Ключевые слова: конкурентоспособность, гудвил, туризм, туристический бизнес, эфффективность, конкуренция.

\section{Kylynchuk O.E.}

Ph.D. in Economics, Assistant

Department of Tourism business and recreation

Odessa National Academy of Food Technologies

Kanatna str., 112, Odessa, Ukraine, 65039

E-mail: Kilinchyk@gmail.com

\section{EFFECT OF GOODWILL TO IMPROVE COMPETITIVENESS IN TOURISM}

In the article the basic indicators that form the positive goodwill of tourist enterprises and their impact on competitiveness. Grounded potential goodwill as a set of behavioral traits typical of tourist companies produced during her stay in the tourist market. A component of the tourist potential of the company 
reputation as elusive character set of factors, including aspects of the relationship between tourism enterprises and customers. Currently, an important issue for a decision on the choice of an effective policy of the company in the sphere of tourist business is a management problem goodwill of travel companies, as goodwill is part of the fixed assets.

On this basis, the development of recommendations to help the management of travel companies significantly increase the degree of competitiveness and operational efficiency. The urgency of this problem can be clearly seen on the market of tourist services in today's financial instability. The effectiveness of the tourism business is largely determined by external factors in the functioning of tourist organizations. The fundamental factor is the external competitive environment of tourism entities, which in the current economic circumstances characterized by a high degree of uncertainty, as it involves a lot of actors, goals and motives which provide hard enough.

To achieve maximum business efficiency Tourism Organization should monitor macroeconomic factors of the competitive environment (demographic, economic, technological, political-legal and socio-cultural) and microfactors competitive environment (customers, competitors, distribution channels, suppliers). In the practice of Ukrainian tourist business is undervalued fashion element, so there is no strong links between business and reputation costs. Goodwill increases the attractiveness of the company to investors, increase its capitalization, strengthens the position when entering new markets and support for the general population. Influence of growth of goodwill and strengthen it to improve the economic performance of tourism enterprises is manifested through behavior and interest of customers who bought the enterprise services; investors who invest in shares of the company; partners, trust company; employees; local community. Assessment of the economic essence of goodwill increasingly interested tourist companies due to market instability.

Keywords: competitiveness, goodwill, tourism, tourism business, efficiency, competition.

\section{References}

1. Dmytryev, M. N., Zabaeva, M. N., \& Maluhyna, E. N. (2010). Ekonomyka turystycheskoho runka. M.: Yunyty-Dana.

2. Temnui, I. V., \& Temnaia, L. R. (2003). Ekonomyka turyzma. M.: Sovetskyi sport.

3. Harlow, R. F. (1977). Public relations definitions through the years. Public Relations Review, 3(1), 49-63.

4. Fombrun, C., \& Shanley, M. (1990). Whats in a name? Reputation building and corporate strategy. Academy of Management Journal, 33(2), 233-258.

5. Harris, T. L. (1988). Value - Added Public Relations: The Secret Weapon of Integrated Marketing. Chicago,IL: McGraw Hill.

6. Davies, G., \& Miles, L. (1998). Reputation management: Theory versus practice. Corporate Reputation Review, 2(2), 16-27.

7. Podolna, V. (2011). Podolna V. Kontseptualni osnovy hudvilu yak nematerialnoho aktyvu pidpryiemstva. Stalyi Rozvytok Ekonomiky, 6, 207-211.

8. Hots, L. (2012). Metodyky vyznachennia vartosti hudvilu. Prometei, 1(37), 140-143.

9. Zobkova, Z. O., Pakhomov, A. V., \& Pakhomova, E. A. (2008). Kompleksnui podkhod k otsenke delovoi reputatsyy predpryiatyia. Matematyka. Kompiuter. Obrazovanye, 1, 150-153.

10. Baturyna, O. (2004). Yssleduem korporatyvnuiu kulturu. Kadrovui Menedzhment, 5(18), 65-68.

11. Kiptenko, V. K. (2010). Menedzhment turyzmu. K.: Znannia.

12. Shkonda, V. V., \& Kalianov, A. V. (2009). Korporatyvna kultura v upravlinni liudskym potentsialom. Donetsk: Noulidzh.

13. Mykhailichenko, H. I. (2012). Innovatsiinyi rozvytok turystychnykh pidpryiemstv: Napriamy zmin ta faktory vplyvu. Ekonomika. Upravlinnia. Innovatsii, 1(7). Retrieved from http://uk.libebook.com/41kulturologiya/1695159-1-udk-371134-33848-mihaylichenko-gi-ken-docent-doktorant-kiivskiy-

nacionalniy-torgovelno-ekonomichniy-universitet-innova.php

14. Pro vnesennia zmin do pereliku napriamiv ta spetsialnostei, za yakymy zdiisniuietsia pidhotovka fakhivtsiv u vyshchykh navchalnykh zakladakh za vidpovidnymy osvitno-kvalifikatsiinymy rivniamy. Retrieved from http://zakon.rada.gov.ua/cgi-bin/laws/main.cgi?nreg=z0854-04.

15. Chaplinskyi, I. B. (2011). Model upravlinnia marketynhovoiu diialnistiu turystychnoho pidpryiemstva.

Visnyk Chernivetskoho Torhovelno-ekonomichnoho Instytutu, 1(41), 42. Retrieved from http://www.chteiknteu.cv.ua/herald/content/download/archive/2011/v1/NV-2011-V1_42.pdf

Kontakt.

16. Daulinh, H. (2003). Reputatsiia firmy. Stvorennia, upravlinnia ta otsinka efektyvnosti. M.: IMIDZh- 